\title{
EXPERIENCES OF MOTHERS AND FATHERS OF CHILDREN AND ADOLESCENTS WITH CANCER: A PHENOMENOLOGICAL-EXISTENTIAL HEIDEGGERIAN APPROACH
}

\author{
Gabriella Michel dos Santos Benedetti ${ }^{1}$, Ieda Harumi Higarashi², Catarina Aparecida Sales ${ }^{3}$
}

\footnotetext{
${ }^{1}$ M.Sc. in Nursing. Collaborative Professor of the Department of Nursing, Universidade Estadual do Paraná. Paranavaí, Paraná, Brazil. Email: enfermeiragabi@hotmail.com

${ }^{2}$ Ph.D. in Education. Associate Professor of Universidade Estadual de Maringá (UEM). Maringá, Paraná, Brazil. Email: ieda1618@ gmail.com

${ }^{3}$ Ph.D. in Nursing. Associate Professor of the UEM. Maringá, Paraná, Brazil. Email: catasales@hotmail.com
}

\begin{abstract}
This study was based in Heideggerian existential phenomenology, and aims to understand the experiences of mothers/ fathers of children and adolescents with cancer. A total of 13 parents of eight patients attended by a charitable association participated, between December 2011 and March 2012. They were asked the question: how has it been for you to experience having a child with cancer? Three issues emerged from the analysis: experiencing the being-present and the being-absent of the loved one; sharing the existential sadness of the child; and learning with the ill child. It was evidenced that these parents experience unexpected transformations in their routine, triggering uncertainties, fears and distress. The same distress that makes them suffer in this world, however, makes them understand the existential condition of the child and of themselves. It is essential that professionals - such as those of nursing - transpose the technical-scientific care and seek to understand these existential needs with a view to offering comprehensive and humanized care.
\end{abstract} DESCRIPTORS: Parents. Child. Adolescent. Neoplasms. Nursing.

\section{VIVÊNCIAS DE PAIS/MÃES DE CRIANÇAS E ADOLESCENTES COM CÂNCER: UMA ABORDAGEM FENOMENOLÓGICO-EXISTENCIAL HEIDEGGERIANA}

\begin{abstract}
RESUMO: Pesquisa baseada na fenomenologia existencial heideggeriana, que objetivou compreender as vivências de pais/mães de crianças e adolescentes com câncer. Participaram 13 pais de oito pacientes, atendidos por uma associação beneficente do noroeste do Paraná, entre dezembro/2011 e março/2012, quando foram inquiridos com a questão: como tem sido para você vivenciar a experiência de ter um filho com câncer? Da análise, emergiram três temáticas: experienciando o estar presente e o estar ausente de o ente querido; compartilhando a tristeza existencial do filho; e aprendendo com o filho doente. Evidenciou-se que estes pais experimentam imprevistas transformações no cotidiano, desencadeando incertezas, medos e angústias. Entretanto, a mesma angústia que os faz quedarem-se diante do mundo, fá-los compreender a condição existencial do filho e de si próprios. Torna-se imprescindível que profissionais, como os da enfermagem, transponham o cuidado técnico-científico e busquem compreender suas necessidades existenciais com vistas a oferecer um cuidado integral e humanizado.
\end{abstract}

DESCRITORES: Pais. Criança. Adolescente. Neoplasias. Enfermagem.

\section{EXPERIENCIAS DE PADRES/MADRES DE NIÑOS Y ADOLESCENTES CON CÁNCER: UNA APROXIMACIÓN FENOMENOLÓGICA EXISTENCIAL-HEIDEGGERIANA}

RESUMEN: Investigación basada en la fenomenología existencial heideggeriana que tuvo por objetivo comprender las vivencias de padres/madres de niño y adolescentes con cáncer. Participaron 13 padres de ocho pacientes, atendidos por una asociación de ayuda del noroeste de Paraná, entre diciembre/2011 y marzo/2012, cuando fueron encuestados con la pregunta: ¿Cómo ha sido para usted vivenciar la experiencia de tener un hijo con cáncer? Del análisis surgieron tres temáticas: experiencia de estar presente y el estar ausente del ente querido; compartiendo la tristeza existencial del hijo y aprendiendo con el hijo enfermo. Se evidenció que esos padres experimentan imprevistas transformaciones en el cotidiano desencadenando incertidumbre, miedos y angustias. Sin embargo, la misma angustia que los hace detenerse delante del mundo, los hará comprender la condición existencial del hijo y de sí mismos. Se hace imprescindible que los profesionales, como la enfermería, transpongamos el cuidado técnico-científico y busquemos comprender sus necesidades existenciales con el objetivo de ofrecer un cuidado integral y humanizado.

DESCRIPTORES: Padres. Niño. Adolescente. Neoplasias. Enfermería. 


\section{INTRODUCTION}

Cancer exercises a negative impact on peoples' lives, not only because of its social and economic repercussions, but also because of the emotional exhaustion to which the patient and her family are exposed. Although it is considered to be a treatable chronic illness which, in many situations, can be cured, above all when diagnosed early, it continues to be stigmatized and full of mystery and suffering. ${ }^{1}$

When the cancer takes place in the early years of life, the distress takes even greater proportions, as the child is experiencing the beginning of her journey, growing and developing in the presence of a disease which threatens and condemns her. ${ }^{2}$

Although rare when compared with tumors in adults, cancer in childhood and adolescence is responsible for 2 to $3 \%$ of all malignant tumors. In addition to this, at the time of writing, it represents the main cause of death by disease in this group. ${ }^{3}$ In this epidemiological scenario, the diagnosis of cancer in children and adolescents does not always take place at an early stage as it should, because of the vagueness of its manifestations, such as fever, paleness and headache, among others; in general, it appears discreetly, this possibly being an explanation for the delay in its diagnosis. ${ }^{4-5}$

From the appearance of suggestive symptoms through to the specification of the diagnosis, the family becomes apprehensive, sensing that something very serious is to invade their lives. Fear in the face of the unknown and the feeling of impotence in the face of the uncontrollable are experienced intensely, ${ }^{4,6}$ as it is known that cancer in childhood, and its treatment, are not experiences easy to cope with. The disease involves a series of stressors, represented by the moment of diagnosis, the undertaking of invasive procedures, and hospitalizations, in which it is not only the child who is affected. The parents who experience these events from close by are significantly impacted. ${ }^{7}$

When the diagnosis is finally confirmed, the possibility of death becomes real, making it difficult for the parents to accept this fact in the life of their child. Studies demonstrate that it is as if their lives were paralyzed as a result of the harm to the professional routine and the need - which is not uncommon - to cease working. Furthermore, the family dynamics are altered, as they cannot take care of the house and give attention to the other children and the spouse, in addition to having their self-care compromised and having to renounce their personal desires and needs. ${ }^{5,8}$ It is common for them to develop physical and emotional symptoms, as they may undergo a hard experience, full of pain and despair. ${ }^{9-11}$

Thus, we ascertained that having a child with cancer represents an extremely exhausting event for the parents, capable of compromising various aspects of their lives. ${ }^{12}$ This exhaustion is strengthened when one considers the fact that complications arising from the disease and the intensity of the treatment are rarely modifiable, ${ }^{13}$ leading them to confront, from the beginning of the disease, a reality of threats, characterized by separations, losses, frustrations and changes. ${ }^{8}$

In the light of the above, we note the extent to which parents suffer with the illness of a child through cancer, finding themselves face-to-face with a disease which brings with it a harbinger of death. They experience various transformations in their lives; most of the time they are not prepared to confront these, and feel frightened, insecure and hopeless. Such reflections awoke in us the following question: How do the parents of children and adolescents with cancer experience this event? To this end, the objective of this study was to understand the experiences of mothers and/or fathers of children and adolescents with cancer.

In our opinion, studies with this focus are justified, as the epidemiological data shows that, in Brazil, from five years of age onward, cancer is considered the first cause of death by disease in both sexes. This context, permeated by the facticity of each human being in the world at the mercy of fatalities, leads us to believe that parents increasingly experience in their existence the experience of having children and/or adolescents with cancer who will need to be embraced and understood by health professionals, especially nurses. They are weak, given that, at these times, they go through emotional suffering and physical exhaustion caused by the disease and its treatment. This requires the understanding of these beings' destitution of care, which includes the identification and consideration of their biopsychosocial needs for the planning of the health actions and programs, with a view to the growing qualification of the professionals and, as a result, of the care provided by them.

\section{METHOD}

This is a qualitative study with a phenomenological approach. The choice of this approach 
was made as a result of its theoretical-philosophical premises allowing nursing investigations to make an analysis and an understanding regarding health, as it seeks to understand Man in his being-in-the-world, that is, in his experiences and relations with the routine world, revealing the subjectivities of the phenomenon experienced. ${ }^{14}$

In this perspective, the Heideggerian existential phenomenology, as a philosophical framework, contributes to research in Nursing, as it allows the researcher to aim to explain the meaning of the Being based in the description of these experiences..$^{15}$ In this search to understand Man in his facticity, we intend to reveal the way of being manifested by him in his discourse, it being possible therefore, to reveal the phenomenon which is shown through the intermediation of the being itself. ${ }^{16}$

Hence, the region of inquiry, or the onticontological region, was constituted by the situation in which the phenomenon which we propose to unveil occurred, that is, the experiences of mothers and/or fathers who experienced cancer in children or adolescents in the life of a child.

Thus, the present study's undertaking took place in a charitable association, located in a municipality in the northwest of Paraná, which provides social and nursing care, including in the home, to 120 low-income patients with cancer and their families.

In order to survey the participants, we firstly located all the records of children and adolescents attended by the association, finding eight families who had a child or adolescent with cancer.

Thus, we opted to include as research participants all the mothers and/or fathers, whether biological or not, of these children or adolescents with cancer aged between zero and 19 years old in accordance with the definition of cancer in children and adolescents presented by the Brazilian National Cancer Institute, ${ }^{3}$ who accepted to participate in the study, were able to clearly verbalize their experiences of coexisting with the ill child, whose child was in treatment or periodical monitoring following the conclusion of the treatment, and whose names were recorded in the association during the period in which the interviews were held.

Following the initial contacts, undertaken over the telephone or at the addresses provided, we explained to them the study objectives, the importance of their participation, and evaluated the extent to which they satisfied the inclusion criteria.
In this process, of the eight families located, only five fathers and all eight mothers, of eight children and/or adolescents with cancer, met the inclusion criteria. The exclusion of three fathers in the study occurred because two of them did not live with the ill child and it was not possible to contact them, and one declined to participate in the study. As a result there was a total of 13 participants.

To these we requested the arrangement of a first meeting, with between one and three visits being undertaken to establish trust, with the aim that mutual empathy should appear, that is, that the parents should feel secure in talking about their experiences and that we also should feel ready to hear them.

In the phenomenological approach, the researcher has a question and goes through it with the intention of understanding it. For this, this concern needs to be presented to the researcher as a phenomenon, that is, as something which needs to be revealed, an "illumination". In this way of thinking, we used, as the guiding question, the following: How has it been for you to experience having a child with cancer?

The interviews were held on days and times, and in places, preferred by the family members, in the period December 2011 - March 2012, lasting for a mean of 31 minutes. The reports were recorded with a digital recorder and later transcribed in full for subsequent analysis.

In order to capture the fullness expressed by the subject in their languages, we opted for the individual analysis of each discourse. Hence, a priori, we undertook close reading of each account, separating the sections or units of meaning (U.M) which, to us, were shown to be fundamental structures of the existence of the participants interviewed. ${ }^{17} \mathrm{~A}$ posteriori, we analyzed the units of meaning of each account, undertaking a phenomenological selection of the language of each subject, ${ }^{17}$ which gave rise to the ontological themes, analyzed in the light of some Heideggerian ideas, as well as those of scholars of this issue and researchers who focus on cancer in children and adolescents.

As this is a study involving human beings, we complied with all of the ethical and legal precepts regulated by Resolution N. 466/12 of the Brazilian Ministry of Health's National Health Council (CNS-MS). The research project was submitted to, and approved by, Maringá State University's Permanent Committee for Ethics in Research involving Human Beings, under Opinion n. 714/2011. The authorization to participate in the study was 
recorded through the administration of the Terms of Free and Informed Consent, in two copies with identical content, following the previous and complete instruction of the research participants.

We clarified that, in order to preserve the witnesses' anonymity, and not simply to denominate them generically (S1... S2...), we started based on uniquenesses expressed by them and learned by us during the meetings, referring to them using the names of precious stones. This decision was owed to the fact that we could see that, just as precious stones suffer wear and cutting in the process of cutting in order to become beautiful and brilliant, ${ }^{18}$ we perceived them as being polished in the light of their facticity, ascertaining, through the mediation of their discourses that in some way, they are improving as human beings, learning and/or maturing through the illness of the children.

\section{RESULTS}

Of the 13 participants in the study, belonging to eight families, five were fathers and eight were mothers, with ages varying between 21 and 74 years old, the majority married/ cohabiting and Roman Catholic by religion; only two were educated to degree level. Their professions were: one worker involved in bagging goods, one driver, one gold/silversmith, one retired farm laborer, one analyst, two artisans and one teacher, as well as five who described themselves as house-wives/ husbands. Of the eight children with cancer, four were children aged between 10 months and 11 years old: two had Wilm's tumors, one with a pelvic tumor and one a bone tumor; four were adolescents, aged between 12 and 18 years old: one with testicular rhabdomyosarcoma, one with leukemia, one with a brain tumor, and one with lymphoma. Of this total, four were undertaking some form of treatment (surgical, chemotherapy, radiotherapy and/or drug-based) while four were being monitored periodically.

After the analysis of the participants' language, three ontological themes emerged: experiencing the being-present and the being-absent of the loved one; sharing the child's existential sadness, and learning with the ill child, presented below.

\section{Experiencing the being-present and the being-absent of the loved one}

It is certain that receiving the news that a child has cancer causes profound sadness and concern in parents; feelings which are soon added to the distress of experiencing painful separations resulting from the travelling necessary in order to undertake treatment and monitoring of the disease in specialized centers.

[...] they nearly never stayed at home, they stayed more in the hospital, and we missed him a lot [...] (Alexandrite); [...] because they were there and this could be the solution. I carried on at work, and they were there. What's terrible is the distance, you feel useless in spite of having to work. So many, many times I thought about quitting everything and running to be by his side [cries] (Opal).

The parents who accompany the ill child in the incessant search for the cure suffer as much with the distance as the parents who are responsible for the house and the other children: [...] because I had hardly arrived and already had to return. My other boy and my husband stayed at home [...]. We spent three months there without coming here, it was three months. My God, it was a struggle, a lot of distress, and staying in other peoples' houses [...]. I had to leave my oldest son with my mother [...] (Aquamarine); [...] I quit work, I left my house, my other daughter, I left everything to run after doctors for him [...] (Pink Tourmaline); It is not easy for you to leave your home and live in another world for a year and a half of treatment, you leave your house and you go and live in another house, with other experiences. [...] I had to abandon my house, abandon my daughter. My daughter stayed with my mother [...] (Pearl).

We also evidenced, through the discourses, that even the marital union can be harmed by the distancing: the marriage in itself, you know, it is a stress to be far from home, caring for my daughter, my husband here working, far away. [...] our marriage ended up being worn out, maybe, I don't know, because of her disease. I am not going to say it is her fault, but it ends up, whether you want it to or not, influencing a bit, whether you want to or not, you end up drifting apart [...] (Ruby).

\section{Sharing the child's existential sadness}

In the participants' language, we noted the extent to which they keep themselves involved in this process of illness. It is as if they felt the same pains through which their children pass and, demonstrating compassion regarding their afflictions, walk with them through this vale of suffering.

How many times did I suffer, seeing her there wanting to eat a salad [...] I suffered and was happy at the same time to see her happiness in being able to eat a salad when she went to do an examination and saw that 
her immunity was a little better [...] (Turquoise); [...] I asked him what it was, he opened up and said "Dad, I can't stand it any longer, I need to go out, I see my friends picking up girls, my friends are getting all the girls and here I am stuck here". That day hurt me deeply, you know [cries]?! I talked with him for a time [cries, trying to breathe], I left him in the sitting room and went to my bedroom to cry [...] (Opal); It is difficult you know, pretty annoying, because he suffers, but we suffer more, because we have to accompany him, and see all his suffering. These four years have been very difficult [...] (Sapphire).

These parents are taken by deep distress, which makes them question and become indignant regarding this occurrence.

Why did it have to be him? Why not me, a sinner? He doesn't understand anything, he doesn't even know what is happening [...] (Emerald).

However, in coexisting with a child with cancer, they also note that, in some way, they are able to alleviate the discomforts of their little jewel.

During this year and a half he hasn't done very much, we isolated the family, because isolating just him is not fair, we have to go into this together and work together for the treatment to work [...]. Because you give yourself one to the other, like we did, we gave ourselves for him (Pearl); There in the hospital, when it was just her and me, we played a lot, she even had a notebook, like a diary, which in the beginning, she couldn't hold up, I wrote a load of stuff in it, she would speak and I would write it down: 'today the chemotherapy treatment started and so on and so forth'. I wrote about 10 pages for her, but I think she lost heart, because she saw it was going to be a long haul, so we stopped (Topaz); I also used a mask, because of her using one, so she wouldn't feel embarrassed. Everywhere she went, she was wearing a mask, she didn't go anywhere without one: if she went to the temple, she used one; inside the house, she used one, if I went to school with her, I put on a mask and she went wearing a mask (Amber).

\section{Learning with the ill child}

Because of the child's illness, these parents are led to seek ways of understanding and overcoming their facticity, when they succeed in identifying something positive in this painful experience.

Finally, we started reacting and raising his selfesteem. He, as he can play and sing, managed to shrug off everything he was feeling and we changed the bad scenario to a good one, such as learning from what was being very difficult for us (Pearl); Today, more mature, sometimes, I much prefer being thankful to complaining. I am learning through this, I think there are people in far worse situations than mine, and there are, I'm still in a position to give love and tenderness to my child [...] (Diamond); So, these things happen, but we have to learn, I am trying, because I am living through this, [...] What has to be will be, there's no way we can change that, I'm well aware of this. I don't know when, but I know it will happen. Of course we don't want this, but may it be as God wills. It's always going to be a shock, a fright, but I am firm (Ruby).

In this path full of thorns, the parents find meanings and renew forgotten values.

This situation brought very important meaning to us, relating to our children. I think that this was very important for me, because, sometimes, I would come home, and if there was some matter to resolve, I would go out, I didn't have the time. Not anymore, today I can see that I have more attention for them (Citrine).

\section{DISCUSSION}

The existential analysis elaborated in Being and Time ${ }^{16}$ proposes a profound reflection of the human being, analyzing her constitutive way of being, that is, the fluidity of her existing. Furthermore, in the existing, the Being-there confirms the fact that she was thrown in the world, in a situation without opportunities for choice, which leads her to experience unplanned and unexpected situations. Hence, when cancer is discovered in a child and awareness is gained that the hard pilgrimage in search of the cure will bring with it solitude and the feeling of abandonment, the world in which the Being-there exists sinks into insignificance, and the world which opens up to her brings with it the pain of distancing from the beings who shared her existence.

Through this, we ascertained, from the language of the interviewees, that the disease and its treatment, as a being who came to the parents, brought with it unforeseen separations, causing suffering and anger, given that distancing oneself from one's child, at this time, is configured as something unacceptable for the father/mother who remains at home. In the same way, for the father/mother who accompanies the ill child, distancing oneself from the family and the home, their refuge, causes them to feel unprotected and distressed, suffering in a world which is utterly unfamiliar.

We also noted that, in distancing themselves from the healthy children, these parents experience a conflict between being-with the ill child and thinking that they leave the healthy child unsup- 
ported, awakening in them the interior feeling of guilt, because of feeling that they abandon and forget the other children, corroborating a recent study. ${ }^{19}$ Thus, experiencing this situation becomes painful, as it can trigger distressful feelings related to the performance of her role as mother. ${ }^{5,11}$

In the Heideggerian concept, the distress which the parents reveal in their accounts exposes their interior state, given that they had to experience a situation which, for them, was unknown. It consists of a threat to the existence of the being in distress, and is that which is found nowhere, which is inhospitable, there being no familiarity with its routine. ${ }^{16}$

The distancing between spouses was also verified in the discourses. This distancing transposes the geographical dimensions and impacts on the affective involvement which unites them, and can weaken this, as, at that time, they are entirely and only concerned with the care for the child. On these occasions, the conjugal relation is influenced by the long duration of the treatment, as the need for frequent travel is perceived as a factor which compromises this union, above all through the distance involved. ${ }^{8}$ Furthermore, the lack of communication and of opportunities to express feelings, added to the harm entailed to their sex life, can contribute to the conjugal separations of parents of children with cancer. ${ }^{19}$

Regarding these questions, the literature indicates that unexpected transformations involving the treatment and hospitalization in the family dynamic entail discomfort for the parents, as these may be deprived of coexistence with friends, their spouse, and the other children, deprived of trips and relaxation. ${ }^{20}$

The essence of the Being-there lies in its existence, evidencing that we can only understand its experience if we submerge ourselves in its existentiality. ${ }^{16}$ Thus, faced with so many necessary separations, addressing such questions remote from the existentiality of the person who experiences this phenomenon, within a practical vision of empiricism, is to fail to involve oneself with the authenticity of the being-in-the-worldness of these beings' world. ${ }^{5}$ In this regard, for us, nurses, to be able to care for the other, we need to understand him in his existential dimension, which involves an existing full of feelings and meanings. ${ }^{21}$

In Heideggerian thinking, Man, as a beingin-the-world, discovers himself as being-with (Mit Sein), in which the other (Mit Dasein) is also a being-in-the-world, that is, a being for the other, in a co-existence. And it is being-with-other that Man distinguishes the possibility of Being-with: somebody not only as a care object, but, in an involving and significant way, as, in the disease, the co-presence does not occupy, but is concerned with, the other. ${ }^{16}$

In the interviewees' language, we learn their unhappiness in feeling themselves to be impotent in the face of the child's existential condition, as the disease causes the child to live a life which should not belong to him. And, even transmitting to the child their love and care, their presence cannot fill the existential emptiness which the child brings with herself, bearing in mind the impossibility of enjoying a healthy life as before.

In these situations, the parents experience the pain and agony in witnessing the physical, social and emotional limitations imposed on their children by the cancer, which interfere significantly in their family, school and community lives..$^{20}$ As a result of this, they do not accept that the disease has penetrated the life of the child, even wishing they could take the child's place if this were possible.

However, at some point of its trajectory, this afflicted living can lead them to understand the child's existential condition, making them able to take up a new awareness regarding the facticity which is presented. Therefore, transposing the care as a simple and pure act of caring, this comes to be configured as a path of openness to the innumerable possibilities to be unveiled. ${ }^{22}$

It is when the Being-there opens to itself its own being that this openness eliminates obstructions, concealments, obfuscations and is shown as itself. ${ }^{16}$ In this showing in its clarity, the parents are revealed as authentic caregivers, taking on sharing, with their loved one, the painful temporality of the treatment, and finding ways of mitigating their suffering.

Through understanding their existential condition, these parents reveal themselves to be a being of concern, throwing themselves beyond the possible and simple to do, and doing what is urgent and inevitable and doing of what is urgent and inevitable, especially in the solicitude with the beings who are shown to be significant to them. ${ }^{23}$ In this way, the parents' immediate concern is to minimize - due to the impossibility of eliminating - the afflictions which their children have experienced, cherishing them with the love and dedication which they carry in their hearts.

In the Heideggerian existential analysis, after the world and the being who lives in the world, 
the Being-in completes the third structural moment of the being-in-the-world, corresponding to the opening itself of the man to the world. It is the understanding which allows the openness of the Being-there, such that, taking up once more his existential meaning, he develops an understanding of his situation. ${ }^{16}$ He projects not only the world, but a horizon of routine concerns, but his power being authentic. ${ }^{24}$

Man is capable of transcending his own pain, manifesting himself in distinct ways, so as to take possession of the world around him. The Beingthere comes to live authentically in the world, becoming a Being of concern for himself and the other, that is, to transcend indicates that the man, in his being-thrown-in-the-world is enabled to impute a meaning itself to the Being. ${ }^{16}$

Thus we surmise from the parents' discourses that, although the illness of a child represents an unplanned event in their existence, they seek to overcome this time, tending to extract something positive from this painful experience, learning through the difficulties and maturing as people. As they recognize their possibilities, they perceive that these go beyond the illness, and are as infinite and limited as the love they bear for their children, and it is based on this understanding that they come to understand their existential condition.

In Ruby's account, we glimpse that she demonstrates that she is aware that becoming ill is part of human existence, however, her language expresses how difficult it is to coexist with a disease like cancer, which brings with it the omen of profound vicissitudes and the discomforting presence of the perspective of death. From her corporeality and tone of voice, we could perceive that the same distress, which had brought her so much suffering, had made her emerge from her state of fall and seek strength to confront what, previously, had caused her fear, and, now, was already familiar to her, that is, the possibility of the death of her daughter.

Regarding the issue, one study mentions that it is possible that the suffering experienced by these parents causes them to progress towards their existence, which is important during this experience, because it can favor the search for survival, so as to confront and adapt to this process of illness. ${ }^{25}$ In this way of thinking, the transcendance has a close link with the facticity, that is, there is no transcendence without facticity, as man can only overcome himself when some unexpected event comes to him. ${ }^{24}$
The accounts of the parents resemble the results of recent studies which demonstrates that these, although experiencing feelings such as suffering, pain, distress and despair, pass through experiences which they characterized as being of learning and growth, ${ }^{8}$ making them able to develop compassion, empathy, patience, interior strength and new perspectives on life. ${ }^{9}$

Thus, the suffering caused by the illness of his daughter made Citrine reflect regarding his existence as a father. Beforehand, he was concerned only with the banalities of his routine, but living through this experience caused him to rethink his concerns, reaffirming his presence in the life not only of his ill daughter, but of all his children.

In spite of the upheavals which the situation entails, bringing with it innumerable changes in the family, there is the possibility of understanding oneself existentially, and, independently of everything that is happening, it is possible to learn and to perceive oneself before and after, ${ }^{8}$ there being the opportunity to imprint new meaning on one's own existence.

In the light of the above, the present study depicts the routine of these parents in the time and in the space of their experiences, this possibly being considered as a limiting factor of the study, as it does not allow us to generalize the results. In spite of this, we believe in its relevance as a form of provoking the reflection of the professionals to assist them, in particular those from the nursing team, due to these beings' constant presence in the care. It can incite them to re-think their actions in relation to the valorization of the human being, sensitizing them to transpose the technical and scientific care to base their care in the understanding of the existential needs, so that they may be able to offer physical comfort and psycho-affective, social and even spiritual support, to those parents who experience cancer in the life of their child.

\section{FINAL CONSIDERATIONS}

In penetrating the existential universe of the study participants, we visualized that having a child with cancer leads the parents to experience unforeseen transformations in their routines. They are led to live in a world full of unexpected and entirely unfamiliar events, which cause them affliction, distress, fear, despair and uncertainties, permeating the present and the future of the loved one and themselves. A whirlwind of feelings in- 
volves their life perspectives regarding the ill child, the healthy children, and the spouse.

However, in the existential ambit, interceded by the Heideggerian hermeneutic, we consider the parents' conceptions that the same distress which initially made them remain regarding the world, living in an inauthentic way, causes them to emerge from their banality and become authentic caregivers through understanding their child's existential condition.

Resulting from the process which they experience, at some point of this trajectory, they are able to understand their own existential condition of being thrown in the world as mothers and fathers of children with cancer and, from this, obtain some learning. In the face of the difficulties, they come to value life in all its dimensions, even those which they considered smaller, co-existing with the possibility of death, even without accepting it, becoming aware that this is unstoppable. Thus, through reflection, they turn to themselves and concern themselves with improving their role as parents and human beings, as, in stepping into the arena of life, they recognize as theirs the obligation to give the best of themselves for the sake of the life of their child.

We are driven, therefore, to the reflection on the care practiced, so as to provide a care which covers the needs of these beings-in-the-world. In this context, it is essential to look not only at their physical dimension, but at the totality of their being. In our view, the need is evident for the professional to use the time as a listening tool in order to improve the quality of the care, given that the temporality of co-existing with cancer in children and adolescents in their existences awakens feelings of distress, resulting from not having anybody with whom, nor of having any way, to share the anxieties which cause them physical and mental discomfort, consequently restricting their quality of life.

\section{REFERENCES}

1. Ribeiro AF, Souza CA. O cuidador familiar de doentes com câncer. Arq Cienc Saude [online]. 2010 [acesso 2012 Abr 15]; 17(1). Disponível em: http:/ / www.cienciasdasaude.famerp.br/racs_ol/vol-171/IDL3_jan-mar_2010.pdf

2. Santos MR, Silva L, Misko MD, Poles K, Bousso RS. Desvelando o cuidado humanizado: percepções de enfermeiros em oncologia pediátrica. Texto Contexto Enferm [online]. 2013 Jul-Set [acesso 2014 Jul 04]; 22(3):646-53. Disponível em: http://www.scielo.br/scielo.php?script=sci_ arttext\&pid=S0104-07072013000300010

3. Ministério da Saúde (BR), Instituto Nacional do Câncer, Coordenação de Prevenção e Vigilância do Câncer. Câncer da criança e do adolescente no Brasil: dados dos registros de base populacional e de mortalidade. Rio de Janeiro (RJ): INCA; 2008.

4. Nehmy RMQ, Brito AC, Mota JAC, Oliveira BM. A perspectiva dos pais sobre a obtenção do diagnóstico de leucemia linfóide aguda em crianças e adolescentes: uma experiência no Brasil. Rev Bras Saúde Matern Infant [online]. 2011 [acesso 2012 Jul 04] ;11(3). Disponível em: http://www.scielo.br/ pdf/rbsmi/v11n3/a10v11n3.pdf

5. Santos LF, Marinho KC, Oliveira RR, Siqueira KM, Oliveira LMAC, Peixoto MKAV, et al. Ser mãe de criança com câncer: uma investigação fenomenológica. Rev Enferm UERJ. 2011 Out-Dez; 19(4):626-31.

6. Silva TCO, Barros VF, Hora EC. Experiência de ser um cuidador familiar no câncer infantil. Rev Rene. 2011 Jul-Set; 12(3):526-31.

7. Jobe-Shields L, Aldefer MA, Barrera M, Vannatta K, Currier JM, Phipps S. Parental Depression and family environment predict distress in children prior to stem-cell transplantation. J Dev Behav Pediatr. 2009 Apr; 30(2):140-6.

8. Castro EHB. A experiência do câncer infantil: repercussões familiares, pessoais e sociais. Rev Malestar Subj. 2010 Set; 10(3):971-94.

9. Klassen AF, Gulati S, Granek L, Rosenberg-Yunger ZRS, Watt L, Sung L, et al. Understanding the health impact of caregiving: a qualitative study of immigrant parents and single parents of children with cancer. Qual Life Res. 2012 Nov; 21(9):1595-605.

10. Norberg AL. Pöder U, Ljungman G, von Essen L. Objective and subjective factors as predictors of posttraumatic stress symptoms in parents of children with cancer - a longitudinal study. Plos One. 2012 May; 7(5):1-7.

11. Oliveira RR, Santos LF, Marinho KC, Cordeiro JABL, Salge AKM, Siqueira KM. Ser mãe de um filho em tratamento quimioterápico: uma análise fenomenológica. Ciênc Cuid Saúde. 2010 Abr-Jun; 9(2):374-82.

12. Klassen AF, Raina P, McIntosh C, Sung L, Klaassen RJ, O'Donnell $\mathrm{M}$, et al. Parents of children with cancer: which factors explain differences in healthrelated quality of life. Int J Cancer. 2011 Sep; 129: 1190-8.

13. Barakat LP, Marmer PL, Schwartz LA. Quality of life of adolescents with cancer: family risks and resources. Health Qual Life Outcomes [online]. 2010 [acesso 2012 Fev 02]; 8(63). Disponível em: http:/ / www.biomedcentral.com/content/pdf/1477-75258-63.pdf 
14. Almeida IS, Crivaro ET, Salimena AMO, Souza IEO. $\mathrm{O}$ caminhar da enfermagem em fenomenologia: revisitando a produção acadêmica. Rev Eletr Enferm [online]. 2009 [acesso 2012 Jun 15]; 11(3). Disponível em: http://www.fen.ufg.br/revista/v11/n3/ v11n3a30.htm

15. Duarte MR, Rocha SS. As contribuições da filosofia heideggeriana nas pesquisas sobre o cuidado em enfermagem. Cogitare Enferm. 2011 Abr-Jun; 16(2):361-4.

16. Heidegger M. Ser e tempo. $3^{\mathrm{a}}$ ed. Petrópolis (RJ): Vozes; 2008.

17. Josgrilberg RS. O método fenomenológico e as ciências humanas. In: Castro DSP, Ázar FP, Piccino JD, Josgrilberg RS, organizadores. Fenomenologia e análise do existir. São Paulo (SP): Sobraphe; 2000. p. 75-93.

18. Franco RR, Campos JES. As pedras preciosas: noções fundamentais. São Paulo (SP): Editora São Paulo; 1971.

19. Grau C, Espada MC. Percepciones de los padres de niños enfermos de cáncer sobre los cambios en las relaciones familiares. Psicooncología. 2012; 9(1):125-36.
20. Nascimento CAD, Monteiro EMLM, Vinhais AB, Cavalcanti LL, Ramos MB. O câncer infantil (leucemia): significações de algumas vivências maternas. Rev Rene. 2009 Abr-Jun; 10(2):149-57.

21. Melo LL, Valle ERM. The toy library as a possibility to unveil the daily life of children with cancer under outpatient treatment. Rev Esc Enferm USP [online]. 2010 [acesso 2012 Jul 04]; 44(2):517-25. Disponível em: http://www.scielo.br/pdf/reeusp/v44n2/39.pdf

22. Oliveira MFV, Carraro TE. Cuidado em Heidegger: uma possibilidade ontológica para a enfermagem. Rev Bras Enferm. 2011 Mar-Abr;64(2):376-80.

23. Salci MA, Sales CA, Marcon SS. Sentimentos de mulheres ao receber o diagnóstico de câncer. Rev Enferm UERJ. 2009 Jan-Mar; 17(1):46-51.

24. Sales CA, Schuhli PAP, Santos EM, Waidman MAP, Marcon SS. Vivências dos familiares ao cuidar de um ente esquizofrênico: um enfoque fenomenológico. Rev Eletr Enferm [online]. 2010 [acesso 2012 Jun 28]; 12(3). Disponível em: http:/ / www.fen.ufg.br/ revista/v12/n3/v12n3a06.htm.

25. Angelo M. Ouvindo a voz da família: narrativas sobre sofrimento e espiritualidade. O Mundo da Saúde. 2010 Out-Dez; 34(4):437-43. 